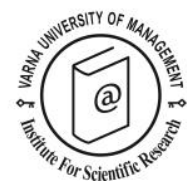

\title{
Political stability and tourism sector development in Mediterranean countries: a panel cointegration and causality analysis
}

\author{
Yilmaz Bayar $^{1 *}$ and Behçet Yener ${ }^{2}$
}

Received: 08/03/2018 Accepted: 25/08/2018

\footnotetext{
1 Usak University, 64100, Turkey, E-mail: yilmaz.bayar@usak.edu.tr

2 Usak University, 64100, Turkey, E-mail: behcetyener@gmail.com

* Corresponding author
}

\begin{abstract}
Tourism sector has become an important source of domestic income for a great number of countries across the world with the contribution of diminishing and removing the barriers over the international mobility of people and considerable developments and cost reductions in transport sector. As a consequence, many countries have designed and implemented various policies to draw tourists and in turn raise their tourism receipts. In this regard, this study investigates the impact of political stability on the development of tourism sector in selected countries from Mediterranean region over the period 2002-2015 with Westerlund (2007) error-correction-based panel cointegration test and Dumitrescu and Hurlin (2012) panel causality test. The findings of the study revealed that political stability had a positive impact on the development of tourism sector in the long run. Furthermore, a two-way causality between tourism sector development and political stability was discovered.
\end{abstract}

(C) 2019 Varna University of Management. All rights reserved

Keywords: political stability, trade openness, tourism sector development, panel data analysis

Citation: Bayar, Y., B. Yener (2019) Political stability and tourism sector development in Mediterranean countries: a panel cointegration and causality analysis. European Journal of Tourism Research 21, pp. 23-32

\section{Introduction}

Tourism sector has become an important source of revenue and an item of international trade together with the globalization and the significant developments and cost reductions in transportation. The number of international tourists have reached 1,235 million in 2016 from 25 million in 1950 globally and the countries hosting the international tourists earned worldwide have increased US\$ 1,220 billion in 2016 from US\$ 2 billion in 1950. Furthermore, international tourists spent about US $\$ 216$ billion for the services of international passenger transportation in 2016. In conclusion, global tourism industry constitutes about $7 \%$ of the global exports of goods and services (UNWTO, 2017). 
Tourism sector includes many economic implications for the national economies. In this regard, tourism can improve the balance of payments, make a contribution to economic growth through increasing the public and private investments in the sector and demand for local goods and services, decrease unemployment by creating jobs and also raise the tax revenues (Pablo-Romero and Molina, 2013). In as much as, the share of travel \& tourism sector in global GDP was $10.4 \%$ and created 313 million jobs in 2017 and this corresponded to the $9.9 \%$ of total employment (World Travel \& Tourism Council, 2018). However, many social, economic and political factors are determinative for tourism attraction. In this paper, we will focus on the effect of political stability and trade openness on the development of tourism sector. Tourism sector is seriously influenced by political instability and violence and malfunctioning resulting from political instability, because the tourists spend money and time to have comfort, fun, and peacefulness. Furthermore, security and risk of incurring losses due to political instability are the crucial factors in decision-making process about destination selection for any tourism types (Saha and Yap, 2014:510). Therefore, political instability is expected to affect the development of tourism sector in theoretical terms.

Mediterranean region including exceptional historical, cultural, and natural places for various tourism types, one of the leading tourism centre with about one third of tourism revenues and half of the number of international tourists in the world (Šimundić and Kuliš, 2016), consists of the countries with different economic development levels, political stability, and openness. The Mediterranean countries experienced significant improvements and deteriorations at their political stability during the 2002-2015 period as seen in Table 1. Especially Albania, Algeria, and Cyprus experienced significant improvements at their political stability, while Egypt, Greece, Lebanon, Tunisia, Turkey, and West Bank and Gaza experienced significant deteriorations at their political stability.

We research the interplay among political stability, trade openness, and tourism revenues for the sample of Mediterranean countries considering their share in global tourism sector and considerable changes in their political

Table 1. Political stability index of Mediterranean countries

\begin{tabular}{lll}
\hline Country & $\mathbf{2 0 0 2}$ & $\mathbf{2 0 1 5}$ \\
\hline Albania & -0.39 & 0.36 \\
Algeria & -1.69 & -1.05 \\
Bosnia and Herzegovina & -0.25 & -0.45 \\
Croatia & 0.52 & 0.58 \\
Cyprus & 0.09 & 0.54 \\
Egypt & -0.46 & -1.34 \\
France & 0.85 & 0.27 \\
Greece & 0.79 & -0.23 \\
Israel & -1.51 & -1.12 \\
Italy & 0.76 & 0.34 \\
Lebanon & -0.45 & -1.72 \\
Malta & 1.52 & 1.04 \\
Morocco & -0.35 & -0.34 \\
Slovenia & 1.20 & 0.92 \\
Spain & 0.39 & 0.29 \\
Tunisia & 0.07 & -0.87 \\
Turkey & -0.87 & -1.28 \\
West Bank and Gaza & -1.76 & -2.13 \\
\hline Source:Won Bank (2017c)
\end{tabular}

Source: World Bank (2017c) 
stability as seen in Table 1 during the study period of 2002-2015. In this context, the paper will be one of the early studies investigating the interaction among tourism development, political stability, and trade openness. The relevant empirical literature was summarized in the next section and Section 3 gives information about dataset and econometric method. Then Section 4 presents the findings of empirical analysis and the paper is concluded with Conclusion section.

\section{Literature Review}

The relevant literature generally has focused on the interaction between tourism-growth considering the quickly growing global tourism sector and most of the studies have revealed that tourism development makes a significant positive contribution to the economic growth (e.g., see Fayissa et al., 2008; Pablo-Romero and Molina, 2013; Antonakakis et al. 2015; Du et al., 2016; Phiri, 2016; Selimi et al., 2017; Shahzad et al. 2017). However, a limited number of scholars have explored the impact of political stability and trade openness on tourism revenues and the studies revealed that political instability affected the tourism development negatively (e.g., see Neumayer, 2004; Basu and Marg, 2012; Ingram et al., 2012; Saha and Yap, 2014; Mushtaq and Zaman, 2014). In other respects, the limited relevant empirical studies examining the interplay between trade openness and tourism development reached mixed findings for different countries (e.g. see, Shan and Wilson, 2001; Habibi et al., 2009; Surugiu and Surugiu, 2011; Santana-Gallego et al., 2016).

Neumayer (2004) researched the effects of various indicators related to the political motivated violence on the development of tourism sector with panel regression analysis and discovered that various forms of political violence affected the development of tourism sector negatively. On the other side, Enders and Sandler (1991) analysed the impact of terrorism on the development of tourism sector in Spain during 1970-1988 period and revealed that terrorism affected tourism sector development negatively. Llorca-Vivero (2008) also researched the effects of terrorism on the tourism development in the world (134 countries) over the period 2001-2003 and revealed that terrorism affected the tourism development negatively. Furthermore, Arana and Leon (2008) reached similar findings with Enders and Sandler (1991) and Llorca-Vivero (2008).

Basu and Marg (2012) researched the impact of political instability consisting of terrorism on the development of tourism sector in Egypt, Jordan and Lebanon from Middle East region during different periods between 1997 and 2011 for each country and discovered that political instability affected tourism receipts negatively. On the other hand, Ingram et al. (2012) investigated the effect of political instability on the development of tourism sector in Thailand with using questionnaire and semistructured interviews and discovered that political instability affected the tourism negatively, but the impact was found to be relatively higher in the respondent who have not been in Thailand before.

Saha and Yap (2014) also examined the effect of political instability and terrorism on the development of tourism sector in terms of revenue and tourist arrivals in 139 countries during the 1999-2009 with regression analysis and discovered that political instability affected the development of tourism sector negatively. On the other side, Mushtaq and Zaman (2014) researched the long-run interplay among political instability, terrorism, and tourism sector development in 4 SAARC (South Asian Association for Regional Cooperation) states including Bangladesh, India, Pakistan, and Sri Lanka over the period 1995-2012 employing panel cointegration analysis and discovered that political instability affected tourism receipts negatively. Ivanov et al. (2017) researched the effect of political stability on the development of tourism sector in Ukraine by the data collected from the questionnaires with hotel and travel agency managers. Their analysis revealed that political instability negatively affected the tourism development in Ukraine.

Shan and Wilson (2001) analysed the causality between international trade and tourism for China with Toda and Yamamoto (1995) test and revealed a bilateral causality between two variables. On the other side, Habibi et al. (2009) explored the major determinants of the 
Political stability and tourism sector development in Mediterranean countries: a panel cointegration and causality analysis.

tourism sector development in Malaysia over 1995-2005 period with dynamic regression analysis and discovered that trade openness had no significant effects on tourism. Surugiu and Surugiu (2011) also analysed the causal interaction between tourism and trade openness in Romania during 1990-2009 period with Granger causality test and revealed a unilateral causality from trade openness to the development tourism sector. Lastly, SantanaGallego et al. (2016) researched the interplay between trade and tourism sector development in 195 countries in 2012 with employing gravity model and found that tourism increased the trade.

\section{Data and Econometric Methodology}

We explored the short and long run interplay among political stability, trade openness, and tourism development in 18 states from Mediterranean region over the period 20022015 with Westerlund (2007) panel cointegration test and Dumitrescu and Hurlin (2012) panel causality test.

\section{Data}

International tourism receipts as \% of GDP (TREV) representing tourism development were used as the explained variable in the study. On the other side, political stability and absence of violence (PS) variable was employed as a proxy for political stability. The value of the PS index indicates the perceptions of the possibility of political instability and/or politically motivated violence, including terrorism and varies between -2.5 and 2.5 (higher values mean higher levels of political stability). PS index was calculated from major information sources obtained from Economist
Intelligence Unit Riskwire \& Democracy Index, World Economic Forum Global Competitiveness Report, Cingranelli Richards Human Rights Database and Political Terror Scale, iJET Country Security Risk Ratings, Institutional Profiles Database, Political Risk Services International Country Risk Guide, and Global Insight Business Conditions and Risk Indicators (see details Kaufmann et al. (2010) and World Bank (2017c)). Also export and import total as \% of GDP representing trade openness (TO) was used as a control variable and all the variables were extracted from the database of World Bank (2017a, 2017b, 2017c, and 2017d).

The existence of data determined study sample and period. The sample consisted of 18 states from Mediterranean region including Albania, Algeria, Bosnia-Herzegovina, Croatia, Cyprus, Egypt, France, Greece, Israel, Italy, Lebanon, Malta, Morocco, Slovenia, Spain, Tunisia, Turkey, and West Bank and Gaza except Gibraltar, Libya, Monaco, Montenegro, and Syria. Stata 14.0, Gauss 11.0, and WinRATS Pro. 8.0 statistical programs were utilized for the conduct of empirical analysis. The correlation matrix of the dataset was displayed in Table 3 and the correlation matrix revealed a positive correlation between both tourism revenues and political stability and trade openness and tourism revenues.

\section{Econometric methodology}

Westerlund (2007) error-correction-based panel cointegration test and Dumitrescu and Hurlin (2012) causality test were used to analyse the interaction among tourism revenues, political stability and trade openness.

Table 2. Dataset summary

\begin{tabular}{lll}
\hline Variables & Explanation & Data Source \\
\hline TREV & International tourism, receipts (\% of GDP) & World Bank (2017a and 2017b) \\
PS & $\begin{array}{l}\text { Political stability and absence of } \\
\text { violence/terrorism }\end{array}$ & World Bank (2017c) \\
TO & Export and import total (\% of GDP) & World Bank (2017d) \\
\hline
\end{tabular}

Table 3. Correlation matrix of the dataset

\begin{tabular}{lll} 
& DTREV & DPS \\
\hline DPS & 0.114130 & \\
DTO & 0.127906 & 0.192581 \\
\hline
\end{tabular}


Westerlund (2007) error-correction-based panel cointegration test considers both crosssectional dependence and heterogeneity and requires that all the series are I(1). The cointegration test includes four cointegration tests based error correction model and in turn calculates four test statistics (two are panel statistics and the others are group statistics). Westerlund (2007) cointegration examines the null hypothesis by investigating that the error correction term equals to zero or not in a conditional error correction model. The null hypothesis asserting that there is no cointegrating relationship is rejected in case the null hypothesis about non-existence of error correction is denied. The simulation results verified that the results of Westerlund (2007) cointegration test are more robust relative to the tests based on residuals such as Pedroni (1999) and (2004) for small samples. At the first stage of the test, the model is estimated with dynamic ordinary least squares as following:

$$
\begin{aligned}
& \Delta Y_{i t}=\delta_{i} d_{t}+\lambda_{i} x_{i t-1}+\sum_{j=1}^{\rho_{i}} \alpha_{i j} \Delta Y_{i t-1}+\sum_{j=0}^{\rho_{i}} \lambda_{i} \Delta x_{i t-j}+\varepsilon_{t} \\
& Y_{i t-1}=\delta_{i} d_{t}+\lambda_{i} x_{i t-1}+\sum_{j=1}^{\rho_{i}} \alpha_{i j} \Delta Y_{i t-1}+\sum_{j=0}^{\rho_{i}} \lambda_{i} \Delta x_{i t-j}+\varepsilon_{t}(2)
\end{aligned}
$$

Then error-correction term and its standard error are calculated for overall panel and the panel cointegrating statistics are calculated as follows:

$$
P_{t}=\frac{\alpha}{S . E(\alpha)} \sim N(0,1) \text { and } P_{\alpha}=T_{\alpha} \sim N(0,1)
$$

Dumitrescu and Hurlin (2012) panel causality test rests on vector autoregression and disregards the cross-sectional dependence, but regards heterogeneity. However, the causality test is able to yield robust results even in case of cross-sectional dependence. Dumitrescu and Hurlin (2012) suggests that Zhnc ( $\mathbf{Z}_{N, T}^{H N C}$ ) test statistic with asymptotic distribution should be taken notice in case of $\mathrm{T}>\mathrm{N}$ and $\mathrm{Ztild}\left(\mathrm{Z}_{N}^{H N C}\right)$ test statistic with semi-asymptotic distribution should be taken in consideration in case of $\mathrm{N}>\mathrm{T}$. The causality test statisticcs are figured as follows:

$$
\begin{gathered}
W_{N, T}^{H N C}=\frac{1}{N} \sum_{i=1}^{N} W_{i, T}\left(W_{i, T} \text { are individual Wald statistics }\right)(4) \\
Z_{N, T}^{H N C}=\sqrt{\frac{N}{2 K}}\left(W_{N, T}^{H C}-K\right) T, N \rightarrow \infty, N(0,1)(5) \\
Z_{N}^{H N C}=\frac{\sqrt{N}\left[W_{N, T}^{H N C}-N^{-1} \sum_{i=1}^{N} E\left(W_{i, T}\right)\right]}{\sqrt{N^{-1} \sum_{i=1}^{N} \operatorname{Var}\left(W_{i, T}\right)}} N \rightarrow \infty, N(0,1)(6)
\end{gathered}
$$

\section{Empirical Analysis}

In the part of empirical analysis, first Pesaran (2004) and Pesaran et al. (2008) crosssectional dependence tests and delta tilde and adjusted delta tilde homogeneity tests of Pesaran and Yamagata (2008) are conducted to see the availability of cross-sectional dependence among the series. Then, Westerlund (2007) panel cointegration test is used to investigate the cointegrating relationship among the variables. Lastly, Dumitrescu and Hurlin (2012) causality test is used to analyse the causal interaction among tourism revenues, political stability and trade openness.

\section{Results of cross-sectional dependence and homogeneity tests}

First, cross-sectional dependence among the cross-section units was analysed with $C D_{L M}$ test of Pesaran (2004) and $L M_{a d j}$. test of Pesaran et al. (2008), since the cross-section size of the dataset $(\mathrm{N}=18)$ was higher than the time dimension of the dataset $(T=14)$. The test results were shown in Table 3 and the null hypothesis (there is cross-sectional independence among the cross-section units) was denied at $5 \%$ level of significance and we revealed the availability of cross-sectional among the series. Then, we analysed the homogeneity of the cointegrating coefficients with adjusted delta tilde test of Pesaran and Yamaga (2008) and the results were shown in Table 4. The null hypothesis (cointegrating coefficients are homogeneous) was denied at $5 \%$ level of significance and we concluded that the cointegrating coefficients differ among the cross-section units.

\section{Results of Pesaran (2007) CIPS unit root test}

The integration levels of the series are important for selection of cointegration test and implementation of causality test. So, the integration levels of the variables were 
Table 4. Cross-sectional dependence and homogeneity test results

\begin{tabular}{|c|c|c|}
\hline \multicolumn{3}{|c|}{ Cross-sectional dependency tests } \\
\hline Variables & $C D_{L M}$ Test Statistic (P value) & $L M_{a d j .}(\mathrm{P}$ value $)$ \\
\hline $\begin{array}{l}\text { TREV } \\
\text { PS } \\
\text { TO }\end{array}$ & $\begin{array}{l}9.562(0.009) \\
12.075(0.015) \\
7.349(0.026)\end{array}$ & $\begin{array}{l}28.905(0.001) \\
14.561(0.004) \\
17.228(0.000)\end{array}$ \\
\hline \multicolumn{3}{|c|}{ Homogeneity tests } \\
\hline Test & Test Statistic & $P$ value \\
\hline 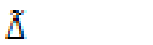 & 18.321 & 0.003 \\
\hline$\overline{\mathbb{Z}}_{a d \tilde{j}}$ & 20.724 & 0.016 \\
\hline
\end{tabular}

Table 5. Panel CIPS unit root test results

\begin{tabular}{lll}
\hline Variables & Constant & Constant+Trend \\
\hline TREV & -1.165 & -1.189 \\
D(TREV) & $-7.552^{*}$ & $-9.569^{*}$ \\
PS & -1.096 & -1.135 \\
D(PS) & $-9.814^{*}$ & $-10.227^{*}$ \\
TO & -0.842 & -0.905 \\
D(TO) & $-9.773^{*}$ & $-9.804^{*}$ \\
\hline
\end{tabular}

Note: Maximum lag length was taken as 2 and optimal lag length was determined considering Schwarz information criterion

* Null hypothesis was rejected at $5 \%$ significance level.

Table 6. Westerlund (2007) panel cointegration test results

\begin{tabular}{lll}
\hline Test Statistic & Value & Bootstrap P Value \\
\hline$G_{\mathrm{t}}$ & -9.562 & 0.016 \\
$G_{a}$ & 8.671 & 0.002 \\
$P_{\mathrm{t}}$ & -9.839 & 0.015 \\
$P_{a}$ & -8.224 & 0.004 \\
\hline
\end{tabular}

analysed with CIPS (cross-sectionally augmented Im-Pesaran-Shin (IPS) (2003)) unit root test Pesaran (2007) considering the existence of cross-sectional dependence among the series and the test results were shown in Table 5 . The results demonstrated that all the variables were I(1).

\section{Westerlund (2007) error-correction-based panel cointegration test results}

The cointgerating relationship among tourism revenues, political stability and trade openness was analysed with Westerlund (2007) panel cointegration test and the test results were shown in Table 6. The group test statistics should be considered due to the existence of cross-sectional dependence among the variables. Also the cointegration statistics should be checked with bootstrap critical values of Chang (2004) in the case of crosssectional dependence (Westerlund, 2007). So the null hypothesis (there are no cointegrating relationship among the variables) was denied and we inferred that there was a long run relationship among the series.

\section{Estimation of cointegrating coefficients}

The long-run coefficients were estimated by FMOLS estimator regarding only heterogeneity and DSUR estimator considering both crosssectional dependence and heterogeneity and the estimations were shown in Table 7. The findings of both FMOLS and DSUR estimators indicated that political stability and trade openness affected the development of tourism sector positively. The estimations by FMOLS revealed that $1 \%$ increase in $\mathrm{PS}$ and $\mathrm{TO}$ respectively raise the tourism revenues by $12 \%$ and $9.3 \%$. On the other side, the estimations by DSUR indicated that $1 \%$ increase in PS and TO respectively raise the tourism revenues by $12.6 \%$ and $10.4 \%$. So both political stability and trade openness were identified to be 
significant determinants for tourist attraction in the long run.

The problems of heteroscedasticity and autocorrelation were eliminated by NeweyWest method.

The globalized world and the improvements in telecommunication enable us to be transiently informed about every development in the world. So, social, economic and political developments have become more important for the tourists in selection of destination for various touristic trips. In this regard, security concern is one of the leading priorities for selection of tourist destination and one step ahead of economic conditions. There is a mutual interaction among political stability, political violence, social unrest, and terrorism which pose a serious threat to the development of tourism sector. The results of the study verified these theoretical considerations for the sample of Mediterranean region. Our findings are also consistent with the relevant literature (especially the findings of Basu and Marg (2012) and Saha and Yap (2014)).

Table 7. Cointegrating coefficients estimation

\begin{tabular}{lllll}
\hline Country & \multicolumn{2}{c}{ PS } & \multicolumn{2}{c}{ TO } \\
\cline { 2 - 5 } & FMOLS & DSUR & FMOLS & DSUR \\
\hline Albania & $0.129^{*}$ & $0.115^{*}$ & $0.094^{*}$ & $0.104^{*}$ \\
Algeria & $0.105^{*}$ & $0.091^{*}$ & $0.042^{*}$ & $0.078^{*}$ \\
Bosnia-Herzegovina & $0.128^{*}$ & $0.125^{*}$ & $0.061^{*}$ & $0.092^{*}$ \\
Croatia & $0.101^{*}$ & $0.112^{*}$ & $0.110^{*}$ & $0.128^{*}$ \\
Cyprus & $0.052^{*}$ & $0.074^{*}$ & $0.074^{*}$ & $0.091^{*}$ \\
Egypt & $0.083^{*}$ & $0.095^{*}$ & $0.036^{*}$ & $0.105^{*}$ \\
France & $0.254^{*}$ & $0.197^{*}$ & $0.142^{*}$ & $0.174^{*}$ \\
Greece & $0.120^{*}$ & $0.138^{*}$ & $0.119^{*}$ & $0.139^{*}$ \\
Israel & $0.103^{*}$ & $0.120^{*}$ & $0.143^{*}$ & $0.125^{*}$ \\
Italy & $0.162^{*}$ & $0.171^{*}$ & $0.179^{*}$ & $0.166^{*}$ \\
Lebanon & $0.094^{*}$ & $0.105^{*}$ & $0.077^{*}$ & $0.062^{*}$ \\
Malta & $0.117^{*}$ & $0.136^{*}$ & $0.112^{*}$ & $0.127^{*}$ \\
Morocco & $0.146^{*}$ & $0.155^{*}$ & $0.074^{*}$ & $0.094^{*}$ \\
Slovenia & $0.103^{*}$ & $0.123^{*}$ & $0.080^{*}$ & $0.042^{*}$ \\
Spain & $0.118^{*}$ & $0.127^{*}$ & $0.162^{*}$ & $0.131^{*}$ \\
Tunisia & $0.132^{*}$ & $0.142^{*}$ & $0.082^{*}$ & $0.090^{*}$ \\
Turkey & $0.135^{*}$ & $0.149^{*}$ & $0.063^{*}$ & $0.073^{*}$ \\
West Bank and Gaza & $0.092^{*}$ & $0.106^{*}$ & $0.041^{*}$ & $0.052^{*}$ \\
Panel & $0.120^{*}$ & $0.126^{*}$ & $0.093^{*}$ & $0.104^{*}$ \\
\hline
\end{tabular}

*significant at $5 \%$ level of significance

Table 8. Dumitrescu and Hurlin (2012) panel causality test results

\begin{tabular}{llll}
\hline Null Hypothesis & Test & Test Statistics & Prob. \\
\hline TREV $\rightarrow$ PS & Whnc & 3.997 & 0.001 \\
& Zhnc & 3.263 & 0.000 \\
& Ztild & 2.564 & 0.017 \\
PS $\rightarrow$ TREV & Whnc & 6.421 & 0.000 \\
& Zhnc & 5.086 & 0.008 \\
TREV $\rightarrow$ TO & Ztild & 3.724 & 0.002 \\
& Whnc & 6.451 & 0.000 \\
& Zhnc & 5.012 & 0.012 \\
TO $\rightarrow$ TREV & Ztild & 4.997 & 0.000 \\
& Whnc & 1.262 & 0.126 \\
& Zhnc & 1.077 & 0.108 \\
& Ztild & 1.009 & 0.137 \\
\hline
\end{tabular}




\section{Dumitrescu and Hurlin (2012) panel causality test}

The causal interplay among tourism development, political stability, and trade openness was analysed with Dumitrescu and Hurlin (2012) causality test and the test results were shown in Table 8. The test results elicited a bidirectional causal interplay between tourism development and political stability and a oneway causality from tourism development to trade openness. So there was a mutual interaction between political stability and tourism development. In other words, political stability feeds the development of tourism sector and in turn tourism sector development feeds the political stability. On the other side, tourism development has significant impact on trade openness by contributing to the transnational flows of goods and services. Moreover, the relevant literature showed that the causal interplay between trade and tourism (from trade to tourism or from tourism to trade) varied as in Surugiu and Surugiu (2011) and Gallego et al. (2016). But in both cases, we can say the existence of mutual interaction between trade and tourism sector development.

\section{Conclusion}

Tourism sector has been expanded significantly in the world together with the globalization process and significant improvements and cost reductions especially in the transport sector. The significant expansion in tourism sector has potential to affect the economies positively through encouraging the public and private investments, improving the balance of payments, and creating jobs. However, many social, economic, political and cultural factors will be determinative in tourist attraction. In this paper, we focused on an untouched area, the interplay between political stability and tourism sector development, in the relevant literature and therefore aimed making a contribution to the relevant literature. So we explored the interplay among political stability, trade openness, and tourism development in 18 states from Mediterranean region over the period 2002-2015 with Westerlund (2007) error correction based panel cointegration test and Dumitrescu and Hurlin (2012) panel causality test. However, data availability constrained the study sample and period.
The findings of the study revealed that political stability and trade openness positively affected the development of tourism sector in the long run. Moreover, the panel causality test revealed a bilateral causal interplay between tourism development and political stability and a unilateral causal interplay from tourism revenues to trade openness. So there was a mutual interaction between political stability and tourism sector development for the sample of Mediterranean countries. However, a different interaction between political stability and tourism development can vary for different groups of countries, because most countries from Mediterranean region such as Albania, Algeria, Lebanon, and Tunisia have not reached the threshold level in the areas of economic and institutional development and legal infrastructure. On the other side, tourism development has significant impact on trade openness by contributing to the transnational flows of goods and services.

The findings of the paper showed that political uncertainty and political motivated violence and security problems significantly affect the development of tourism sector. In this context, establishment of an institutional and legal framework promoting the political stability and diminishing security concerns will also contribute to the development of tourism sector. Future studies can be focused the role of institutions and rule of law in the interplay between political stability and tourism sector development for different groups of countries.

\section{References}

Antonakakis, N., Dragouni, M. \& Filis, G. (2015). How strong is the linkage between tourism and economic growth in Europe? Economic Modelling, 44, 142-155. DOI: 10.1016/j.econmod.2014.10.018

Arana, J.E. \& Leon, C.J. (2008). The impact of terrorism on tourism demand. Annals of Tourism Research, 35(2), 299-315. DOI: 10.1016/j.annals.2007.08.003

Basu, K. \& Marg, V.S. (2012), Impact of Political Instability and Terrorism in the Tourism Industry of Three Middle East Countries: An Economic Exploration, URL: http://www.ijbtsjournal.com/images/main 1366796758/00 02-Kaushik.pdf [Accessed 6.8.2017] 
Chang, Y. (2004). Bootstrap unit root tests in panels with cross-sectional dependency. Journal of Econometrics, 120, 263-293. DOI: 10.1016/S0304-4076(03)00214-8

Du, D., Lew, A.A. \& Ng, P.T. (2016). Tourism and economic growth. Journal of Travel Research, 55(4), 454-464. DOI: $10.1177 / 0047287514563167$

Dumitrescu, E. \& Hurlin, C. (2012). Testing for granger non-causality in heterogeneous panels. Economic Modelling, 29(4), 14501460, OI: 10.1016/j.econmod.2012.02.014

Enders, W. \& Sandler, T. (1991). Causality between transnational terrorism and tourism: The case of Spain. Studies in Conflict \& Terrorism, 14(1), 49-58. DOI: 10.1080/10576109108435856

Fayissa, B., Nsiah, C. \& Tadasse, B. (2008). Impact of tourism on economic growth and development in Africa. Tourism Economics, 14(4), 807-818. DOI: $10.5367 / 000000008786440229$

Habibi, F., Rahim, K.A., Ramchandran, S. \& Chin, L. (2009). Dynamic model for international tourism demand for malaysia: panel data evidence. International Research Journal of Finance and Economics, 33, 207-217.

Im, K. S., Pesaran, M. H.\& Shin, Y. (2003). Testing for Unit Roots in Heterogeneous Panels. Journal of Econometrics, 115(1), 53-74. DOI: 10.1016/S0304-4076(03) 00092-7

Ingram, H., Tabari, S. \& Watthanakhomprathip, W. (2013). The impact of political instability on tourism: case of Thailand. Worldwide Hospitality and Tourism Themes, 5(1), 92-103, DOI:10.1108/ 17554211311292475

Ivanov, S., Gavrilina, M., Webster, C. \& Ralko, V. (2017). Impacts of political instability on the tourism industry in Ukraine. Journal of Policy Research in Tourism, Leisure \& Events, 9(1), 100-127. DOI: 10.1080/19407963.2016.1209677.

Kaufmann, D., Kraay, A. \& Mastruzzi, M. (2010). The Worldwide Governance Indicators: A Summary of Methodology, Data and Analytical Issues. World Bank Policy Research Working Paper No. 5430, http://papers.ssrn.com/sol3/papers.cfm?a bstract_id=1682130 [Accessed 6.8.2017]
Llorca-Vivero, R. (2008). Terrorism and international tourism: New evidence. Defence and Peace Economics, 19(2), 169188. DOI: $10.1080 / 10242690701453917$

Mushtaq, A. \& Zaman, K. (2014). The relationship between political instability, terrorism and tourism in SAARC region. Journal of Economic Info, 1(1), 23-40.

Neumayer, E. (2004). The impact of political violence on tourism: Dynamic crossnational estimation. Journal of Conflict Resolution, 48(2), 259-281

Pablo-Romero, M.P. \& Molina, J.A. (2013). Tourism and economic growth: a review of empirical literature. Tourism Management Perspectives, 8, 28-41. DOI: 10.1016/ j.tmp.2013.05.006

Pedroni, P. (1999). Critical values for cointegration tests in heterogeneous panels with multiple regressors. Oxford Bulletin of Economics and Statistics, 61, 653-670. DOI: 10.1111/1468-0084.0610 s1653

Pedroni, P. (2004). Panel cointegration: asymptotic and finite sample properties of pooled time series tests with an application to the PPP hypothesis. Economic Theory, 20, 597-625. DOI: $10.1017 /$ S0266466604203073

Pesaran, M. H. (2004). General diagnostic test for cross section dependence in panels, Working Paper, University of Cambridge \& USC.

Pesaran, M. H. (2007). A simple panel unit root test in the presence of cross-section dependence. Journal of Applied Econometrics, 22(2), 265-312. DOI: 10.1002/jae.951

Pesaran, M. H., Ullah, A., \& Yamagata, T. (2008). A Bias-Adjusted LM Test of Error Cross Section Independence. Econometrics Journal, 11(1), 105-127. DOI: 10.1111/j.1368-423X.2007.00227.

Pesaran, M. H. \& Yamagata, T. (2008). Testing slope homogeneity in large panels. Journal of Econometrics, 142(1), 50-93. DOI: 10.1016/j.jeconom.2007.05.010

Phiri, A. (2016). Tourism and economic growth in South Africa: Evidence from linear and nonlinear cointegration frameworks. Managing Global Transitions, 14(1), 3153. 
Saha, S. \& Yap, G. (2014). The moderation effects of political instability and terrorism on tourism development: a cross-country panel analysis. Journal of Travel Research, 53(4), 509-521. DOI:10.1177/ 0047287513496472

Santana-Gallego, M., Ledesma-Rodríguez, F.J. \& Pérez-Rodríguez, J.V. (2016). international trade and tourism flows: an extension of the gravity model. Economic Modelling, 52, 1026-1033. DOI: 10.1016/j.econmod.2015.10.043

Selimi, N., Sadiku, M. \& Sadiku, L. (2017). The impact of tourism on economic growth in the Western Balkan countries: An empirical analysis. International Journal of Business and Economic Sciences Applied Research, 10(2), 19-25.

Shahzad, S.J.H., Shahbazad, M., Ferrer, R. \& Ravinesh, R. (2017). Tourism-led growth hypothesis in the top ten tourist destinations: New evidence using the quantile-on-quantile approach. Tourism Management, 60, 223-232. DOI: 10.1016/j.tourman.2016.12.006

Shan, J. \& Wilson, K. (2001). Causality between trade and tourism: empirical evidence from China. Applied Economics Letters, 8, 279-283.

Šimundić, B. \& Kuliš, B. (2016). Tourism and economic growth in Mediterranean region: dynamic panel data approach. Acta Economica Et Turistica, 2(1), 65-84.
Surugiu, C. \& Surugiu, M.R. (2011). Causality between tourism exports and trade openness: empirical analysis for Romanian tourism. Revista Tinerilor Economisti (The Youns Economists Journal), 17, 100-109.

UNWTO (2017). UNWTO Tourism Highlights2017 Edition, URL: http://www.eunwto.org/doi/pdf/10.18111/97892844190 29 [Accessed 26.8.2017]

Westerlund, J. (2007). Testing for error correction in panel data. Oxford Bulletin of Economics and Statistics, 69(6), 709-748. DOI: 10.1111/j.1468-0084.2007.00477.

World Bank (2017a), International Tourism, Receipts (current US\$), URL: http://data.worldbank.org/indicator/ST.INT. RCPT.CD [Accessed 6.8.2017]

World Bank (2017b), GDP (current US\$), URL: http://data.worldbank.org/indicator/NY.GD P.MKTP.CD [Accessed 6.8.2017]

World Bank (2017c). Worldwide Governance Indicators, URL: http://info.worldbank.org/ governance/wgi/\#home, [Accessed 6.8. 2017]

World Bank (2017d). Trade (\% of GDP), http://data.worldbank.org/indicator/NE.TR D.GNFS.ZS, [Accessed 6.8.2017]

World Travel \& Tourism Council (2018). Travel \& Tourism Economic Impact 2018, URL: https://www.wttc.org/-/media/files/reports /economic-impact-research/regions-2018/ world2018.pdf [Accessed 19.8.2018] 